\title{
Peter Bucsky
}

Doctoral School of Earth Sciences of the University of Pécs, Hungary

\section{CHINA - EUROPEAN UNION RAIL FREIGHT TRAFFIC: SLOW GROWTH DESPITE MEDIA SPOTLIGHT}

\begin{abstract}
The Chinese Silk Road concept is attracting more and more attention. It involves (geo)politics, economics, infrastructure and transport development. The idea of faster transport of goods overland via Central-Asia by rail between Europe and China has become very popular, but there has been little attention devoted to the fact that the possibility of direct European Union-China rail freight transport has already existed for decades. This article examines statistical data about the rail traffic between the European Union and China and seeks to provide an answer to the question, what can be the realistic future of this transport connection? Trade data suggests that despite the growth in rail freight transport, this mode will be marginal for the transport links between China and Europe.
\end{abstract}

Keywords: China, European Union, Belt \& Road initiative, Eurasian landbridge, infrastructure, railway

\section{Introduction}

Transport connections between countries are essential for trade, and the quality of routes influences the cost of transport, and so does the quantity of trade. The search for cheaper, faster and more reliable transport connections between the EU and China is rational, as the two blocks account for $25 \%$ of global population and $34 \%$ of global GDP on purchasing power parity. The connection of these two economic blocks is already granted, but further developments are possible.

In 2004, Chinese President Xi Jinping announced that the Chinese government will invest 40 billion USD in the Silk Road infrastructure development, which was increased to 124 billion USD in 2017. However, the chances of developing a new, faster railway system on a 10 ten thousand-kilometre-long route are almost 
non-realistic, as most of it runs sparsely populated areas. Therefore, in the near future the infrastructure may not change dramatically, especially as the bulk of the route passes through Kazakhstan, Russia and Belorussia, where the infrastructure and especially maintenance is poor / insufficient and China is not planning to invest in this countries on a substantial extent.

The New Silk Road concept introduced is therefore not intended to build a completely new infrastructure, but to use the current one better, to try to develop it with further investments, and to create new feeder lines and interconnections. The rail routes connecting Europe and China are important not only for these two economic centres, but also for all countries lying along it, so they are developing it with or without China's financial support. If the development is economically and/ or socially viable the European Bank for Reconstruction and Development (EBRD) or the World Bank will also offer financing tools. Many proposed developments are financially less attractive, or are hindered by political tensions. Even if all proposed new connections were built, the rail freight's travel time and cost would not change considerably. The attractiveness of rail freight transport lies in other economic factors: market development and the changing structures of goods traded along the route. Possible infrastructure developments and plans have been analysed in detail in the literature, but there is less focus on the volume and structure of goods, which would also be at least as much important to understand the viability of the Eurasian landbridge developments.

The aim of this paper is to summarise and synthesize the findings of available literature about what the drivers of the Chinese New Silk Road project's railway developments are, what the supporting and prohibitive factors are, and what the foreseeable future trends are. Furthermore, the collection of data on rail traffic and logistics services on the route of the Eurasian landbridge can also help to better understand current traffic flows and what the future role of the rail freight connection of the two economic centres can be.

\section{The growing importance of the Eurasian landbridge}

\section{The transport consequences of China's economic shift}

The literature analysed the potential of railway traffic between China and Europe from various aspects. The enabler for the growing importance of the topic was that China started to heavily invest in the infrastructure development of the Western parts of the country. The initial goal of the railway and road developments were to connect these regions to the oceans, and not to the Eurasian infrastructure networks. Garver (2006) summarised all the Chinese plans and cooperation to develop infrastructure in the neighbouring countries, and it can be seen that not only the Central-Asian countries were of interest, but the whole Asian region. It is important to note that the development plans included corridors which are more or less the same as in the Silk Road Economic Belt initiative in 2013.

Casarini (2016) analysed the Chinese New Silk Road's implications, and found that its goal is not only to export more Chinese goods, but also to export Chinese 
development models. As Chinese companies are investing more and more in the region, it has become important for them to be able to ship their products to China and/or to Europe. The Central-Asian countries have become also more and more important as a market and it is the interest of Chinese exporters to gain faster and cheaper access with the help of a modern transport network. It can also be seen that in the Chinese plans maritime transport has the main role of intercontinental transport. The shift of goods flow from mainly Western European ports like Rotterdam and Hamburg to Mediterranean ports like Venice and Piraeus - already in Chinese ownership - can be seen as the most direct effect on Europe. In connection with this, China plans to finance the reconstruction of the Budapest-Belgrade railway line as well. This process does not make the traffic cheaper or faster between Europe and China, but can relocate traffic to ports on the Balkans which are in Chinese ownership.

The economic model shift in China makes the Eurasian railway connection more important. With the rise of labour costs, there is a need for Chinese corporations to find cheap labour in the countries of the region where they move the production to. This can be partly in Central-Asia, but the low population of the region - 70 million people which is very low compared to China and it can be a limiting factor. Furthermore, there are numerous kinds of natural reserves in this region, and low environmental standards for their exploitation. Tracy et al. (2017) study the environmental factors of the Silk Road region. From the perspective of transport, the most important conclusion is that some heavy industries such as cement and steel industries, chemicals are currently relocated to the Central-Asian countries, from China and this trend is likely to continue. The rising environmental standards and labour costs in China will further facilitate this process. These heavy industries use and produce bulk materials which are typically transported by rail. The relocation of polluting industries from China along the Silk Road can be seen as one of the main aims of the railway development in the region. Not only the heavy industry but also agricultural production has the potential for development for instance in Tajikistan. Small and large scale Chinese agro corporations are expending rapidly here (Hofman, 2016).

The new Silk Road concept is important for China to have more alternative transport routes to find the way for its goods to the European and Central-Asian market. There are two main reasons for that: the capacities of Chinese ports are increasingly clogged. Since the 2008 global recession China has been more active in encouraging trade and economic cooperation, it has been trying to find new markets for its industrial overcapacities.

The second intention is rather geopolitical: the amount of traffic between China and Europe is valued 1 billion euros per day. As most of the maritime traffic is going across the South China Sea, the Strait of Malacca, between the failed states of Yemen and Somalia, across the Suez Canal in the politically instable Egypt, and Sinai Peninsula with terrorist cells, there is a high security risk for the route. Other alternative routes would be at least twice as long, and thus, could be more expensive than overland rail. The Iron Silk Road developments, building of alternative routes can also serve as a risk mitigation project. 


\section{Bureaucratic and legal challenges}

Rodemann and Templar (2014) analysed the intermodal rail freight between Europa and Asia. They carried out case studies and 24 semi-structured interviews with stakeholders. They state that bulk of intercontinental transport is carried out by sea freight, but the change in supply chain is opening up new possibilities. Due to faster innovation cycles and more personalized goods there is more need for more frequent, smaller quantity and faster transport, which offers a chance for intercontinental rail transport. Transporters can have a third option not only slow but cheap sea, and fast but expensive air. They also conclude that rail connection between the Europe and China is not new, the Trans-Siberian railway, which is also connected to the Chinese network was opened in 1917, and has been used for international traffic since 1936. In 2015 on the Tran-Siberian route 61\% of the traffic was coal, container were not even registered, they are part of the $1 \%$ other traffic type. Currently, block trains with containers are the most typical to run on the China-Europe route, but their capacity is limited to 90-100 TEU that is only a fraction of a 10-20 thousand TEU ship. The authors also analysed travel times, and the advantage of rail is still not great, but it can be considerably improved as $4-5$ days are spent crossing borders. The transport time on the Hamburg-Beijing or Rotterdam- Lianyungang route is 14 days by rail, 23 by truck, $24-25$ by sea. The authors conclude that railway will play a marginal role in Europe-Asia traffic also in the future, but especially for manufacturers of cars and electronics, potentially for dangerous goods it can gain importance.

There are important legal enablers for the Eurasian railway traffic, and one of them is a common waybill. There is a common waybill for European countries (Convention concerning International Carriage by Rail - COTIF), and for the Eastern-European and CIS countries (for OSJD members), the SMPS/SMGS. Since 2006 there has been a common CIM/SMGS waybill, which gave the opportunity to only have one waybill for the whole Europe-Asia rail shipment, and solves legal questions (CIT, 2016). Abramović et al. (2016) showed on the Ukrainian-Slovak rail freight example that the introduction of common waybill, and electronic data transfer between railway corporations could speed up the administrative process of border crossing by 170 minutes, 66,7 percent spent on the border. With this method extended to all borders on Europe-Asia routes, $3-5$ days could be saved on journey times. There is also need for further standardisation of legal background and administrative processes, a common railway standard for the two continents would be desirable, which is still not fulfilled (Leimgruber, 2009).

Diener (2015) concludes that since the break-up of the Soviet Union the Central-Asian countries of the region have shown very limited sign for integration, or any type of collective action. Critics of the New Silk Road project emphasize the importance of this bordered reality, which is the main hindering force for more traffic. With $40+$ enclaves, and numerous ethnical and political conflicts in the region, the prospects of common developments are more than limited. Alff (2016) carried out a research of the socio-economic effects of Chinese trade and transport policy in Kyrgyzstan. The arrival of cheap Chinese consumer goods threatens the livelihood of local merchants and producers, which can lead 
to growing anti-Chinese tensions in the local population, which politics have to tackle. Local actors have adapted to the changing trade and transport realities, and have set up a local sewing business based on cheap Chinese textiles. The kind of trade relations, development or decline of local industries depends on various socio-economic factors which are hard to predict. For the Central-Asian countries the role of China is important as a main partner, as after the break-up of the Soviet Union, Russia left a vacuum here as described by Loughlin and Pannell (2013). Also, they emphasize that for the Xinjiang province the neighbouring countries are important for the development, and common ethnic routes are helpful in this regard.

There are also studies which analyse case studies. Hilletofth et al. (2007) concentrated on container traffic, and concludes that the lead time advantage of railway can be suitable for business cases with the costs for manufacturers. The main problem of companies are the frequent delays which can vary a lot and also the lack of information of estimated arrival times. Companies do not want to deal with the unpredictability of trains, arriving on time can be more important than travel time. Secondly, the tariffs are too high. Most of the services are for full trains, or full containers, smaller quantities are rare on the market. That is the reason why automotive companies are one of the main customers of the Eurasian black trains as they have enough cargo for full trains. We can conclude that higher quality logistics services are needed to make rail transport more appealing.

\section{Practical challenges of the Eurasian landbridge}

\section{The growing importance of Kazakh connection}

The main part of the research is concentrating on the political and infrastructure development segments of the transformation, and there has been little attention devoted to the actual traffic development, which the author tries to achieve in this paper. The overland rail connection between Europe and China has attracted so much media attention albite the possibility for transporting goods by rail between China and Europe has been given for a century through the Trans-Siberian Railway. This connection was opened to Vladivostok in 1917. Tavasszy et al. (2011) created a model for international container traffic. They modelled what routes container traffic would choose between China and Europe if prices on the Eurasian landbridge were the half of European market prices. They found that this way from Germany $12 \%$ of traffic would use the rail connection - but from the Netherlands almost none. The rail container shipments were very price sensitive. From the analysed scenarios - e.g. melting of polar ice, reduction in port fees, and introduction of slow streaming - the rail landbridge had the lowest, almost negligible impact.

The China-Europe railway connections to date are all going across Russia, but China does not want to be dependent on its energy rich neighbour or on anyone. Therefore, it is essential to develop alternative routes. Also, if there are more available routes competing with each other, it can help to reduce transport costs 
and travel time. However, for the coming decade there is no real chance of the route via Turkey or the Caucasus countries to be a viable alternative.

After the easing of political tensions between the Soviet Union and China after 1985, the preparations of a new railway connection began. In 1990 the line from Ürümqi to Alashankou was finished, and connected with the Almaty-Druzba section on the Soviet side. The First freight trains started operation in 1991, passenger trains in 1992 (Otsuka, 2001). Until now this is the fastest railway connection to Europe, which is around 8 thousand $\mathrm{km}$ shorter than the maritime route. Erd si (2015) calculated that the Trans-Siberian route had 420 thousand TEU traffic in 2012, and Kazakh-Chinese route 240 thousand TEU. Although there are other proposed new lines, the travel distance and time cannot be lowered significantly, so this development can be seen as the most important step of Eurasian railway infrastructure development for the connection of European and Chinese rail systems.

Although the railway connection between Kazakhstan and China was built at the beginning of the 90's, there were a number of limitations why traffic was poor. Shu 1997 summarises the main factors as inadequate facilities for the gauge change, inspections and formalities taking up to 6 days. The red tape did not only raise the costs of transport with the time spent on the border, but also fees and taxes were high. The main challenge was and still is the cooperation between CIS and Chinese railways and cutting red tape, but the constant development and efforts paid off.

\section{Inner-Chinese shift of economic functions}

The faster and more reliable railway connection was made possible by Chinese railway development. After the third round of the national railway speed-up project the Longhai line (Lianyungang-Lanzhou) and Lanxin line (Lanzhou-Urumqi) were speeded up, and there was greater capacity for railway freight traffic $(\mathrm{Xu}, 2016)$. This is in line with China's Go West Campaign, to facilitate industrial development in the offshore areas of the country. As a result, new industrial megacities has emerged such as Chongqing and Chengdu. As these cities are $2000 \mathrm{~km}$ from the sea, the travel cost and time is higher for exports, so railway to the European markets is a good alternative.

Hewlett Packard built one of the largest laptop factories in the world in Chongqing, and regularly ships products to Duisburg in Germany by rail. The rapid extension of the Chinese high-speed network also contributed to the speeding up of the freight traffic. According to "The Intermediate and Long-Term Plan for Railway Network", which was published in 2004 by the Ministry of Railways in China, and was revised in 2008, new passenger dedicated lines have been planned, where the conventional tracks - mostly upgraded to at least to $120 \mathrm{~km} / \mathrm{h}$ speed - have been dedicated to freight trains, growing capacity and efficiency. The shift of production from the seaside to $1000-2000 \mathrm{~km}$ inland cities made the trains between Europe and China much more suitable.

The new connections to Xinjiang opened in 2000, on the Lianyungang-Lanzhou-Urumqi route. It was successful in the boosting of Chinese exports to the Central-Asian countries. Ass H. Xu (2016) was able to show that the freight 
volume has risen by $30 \%$. The more efficient eastern territories of China gained faster and cheaper access to the mainland and beyond.

The general understanding is that there is still an ongoing railway revolution in China. This can be true for passenger traffic, but for rail freight it looks as if China is approaching a peak. As the Chinese economy is changing track from extensive to intensive growth, the industry and bulk goods are losing importance. The Made in China 2025 Strategy focuses on the replacement of foreign technology in Chinese industry to local. Other priority is alternative energy, the reduction of growth in coal, steal and construction will have an impact on transport as well. (Wübbeke, 2016).

As Chinese exports of materials and components involve 70-80\% imports, the main goal of the strategy is to lower it to $70 \%$ by 2020 and $40 \%$ by 2025 (Kennedy, 2015). This will have effects on supply chains and there will be fewer imports. In the Made in China 2025 strategy railway does not have a central role, especially not rail freight rail. The only rail related exception is the export of high-tech transportation equipment, namely high-speed trains. As China wants to shift from low-tech industry, this is understandable: rail freight traffic is a low-profit, low-technology industry, there is not too much innovation to be done.

\section{Challenges of cutting red tape}

There are other new connections proposed, namely to Tajikistan and Kyrgyzstan (The Diplomat, 2017). These developments are very important for the landlocked countries of Central-Asia, especially for Uzbekistan, being the only doubly landlocked country in the world. For the European-Chinese traffic, these developments are less relevant. The route across Kazakhstan is the shortest, and also the fastest. As Kazakhstan is part of the Eurasian Economic Union with Russia and Belarus, there is much less bureaucracy involved, customs have to be only declared once on the Chinese-Kazakh border, and then on the EU-Belarus border.

Due to notorious red tape in the Central-Asian country, these are very important factors, especially the high tensions between Uzbekistan and its neighbours. Also, the alternative routes across Central-Asian countries could only continue across the Caspian-sea, which involves time consuming and expensive ferry, or across Turkmenistan and Iran. This is problematic due to EU and US sanctions against Iran - transporting high-tech products, and also involves much more border crossings, which can extend the travel time by days. Also, the terrain makes new projects expensive and excess costs can hinder the economic viability of envisioned projects.

The Uzbek-Turkmen border crossings take alone 100 hours on average (OECD, 2010). There is unfortunately no current data involving multiple countries, but travel times can be influenced more by these factors, than actual train speeds. Even there is no exact data available, the customs transparency index of the World Economic Forum can be a good guideline to highlight the reach of the problem: most of the countries in Central-Asia are in the lower quarter of the rankings, and the probably even less sufficient customs systems of Turkmenistan, Tajikistan and Uzbekistan have not even been considered in the report. 
Table 1. Customs Services in countries along the Silk Route

\begin{tabular}{|l|c|c|c|c|c|}
\hline \multirow{3}{*}{ Country } & $\begin{array}{c}\text { Combined } \\
\text { score }\end{array}$ & \multicolumn{2}{|c|}{$\begin{array}{c}\text { Index of transparency } \\
\text { of procedures } \\
\text { and regulations related } \\
\text { to customs clearance }\end{array}$} & \multicolumn{2}{c|}{$\begin{array}{c}\text { Index of extent of quality } \\
\text { and comprehensiveness } \\
\text { of services provided by } \\
\text { customs authorities }\end{array}$} \\
\cline { 2 - 6 } & Score & Rank & Score & Rank & Score \\
\hline Germany & 0.92 & 1 & 1 & 14 & 0.83 \\
\hline Poland & 0.89 & 1 & 1 & 27 & 0.77 \\
\hline Kyrgyz Republic & 0.79 & 1 & 1 & 66 & 0.58 \\
\hline China & 0.78 & 40 & 0.9 & 50 & 0.65 \\
\hline Russian Federation & 0.65 & 96 & 0.6 & 42 & 0.69 \\
\hline Ukraine & 0.62 & 49 & 0.9 & 110 & 0.33 \\
\hline Kazakhstan & 0.48 & 79 & 0.7 & 114 & 0.25 \\
\hline
\end{tabular}

Remark: 0 - worst, 1 - best, including 117 countries

Source: (own calculations based on: World Economic Forum Database)

The main challenge of the Silk Road development is that the Central-Asian countries are one of the worst performers in logistics services. According to the World Bank's Logistics Performance Index in 2016 only Kazakhstan managed to be part of the upper half of the ranked 160 countries from the region.

Table 2. Rankings of logistics services of countries along the Eurasian landbridge - Logistics Performance Index of the World Bank

\begin{tabular}{|c|c|c|c|c|c|}
\hline \multirow{2}{*}{ Country } & \multicolumn{2}{|c|}{2007} & \multicolumn{2}{|c|}{2016} & \multirow{2}{*}{$\begin{array}{l}\text { Change } \\
\text { in points }\end{array}$} \\
\hline & Points & Rank & Points & Rank & \\
\hline Germany & 4.1 & 3 & 4.23 & 1 & $3 \%$ \\
\hline Czech Republic & 3.13 & 38 & 3.67 & 26 & $17 \%$ \\
\hline China & 3.32 & 30 & 3.66 & 27 & $10 \%$ \\
\hline Poland & 3.04 & 40 & 3.43 & 33 & $13 \%$ \\
\hline Kazakhstan & 2.12 & 133 & 2.75 & 77 & $30 \%$ \\
\hline Ukraine & 2.55 & 73 & 2.74 & 80 & $7 \%$ \\
\hline Russian Federation & 2.37 & 99 & 2.57 & 99 & $9 \%$ \\
\hline Mongolia & 2.08 & 136 & 2.51 & 108 & $20 \%$ \\
\hline Uzbekistan & 2.16 & 129 & 2.4 & 118 & $11 \%$ \\
\hline Belarus & 2.53 & 74 & 2.4 & 120 & $-5 \%$ \\
\hline Turkmenistan & N/A & N/A & 2.21 & 140 & N/A \\
\hline Kyrgyz Republic & 2.35 & 103 & 2.16 & 146 & $-8 \%$ \\
\hline Tajikistan & 1.93 & 146 & 2.06 & 153 & $7 \%$ \\
\hline \multicolumn{2}{|c|}{ Number of countries ranked } & 150 & - & 160 & - \\
\hline
\end{tabular}

Source: (https://pi.worldbank.org/international/global) 


\section{The declining role of railway transport}

\section{General trends in freight modal split}

Both in China and in the EU, railway traffic has lost its importance. Since 1996 the share in ton-kms has dropped from 27 to $12 \%$ in China, while in the EU28 from 14 to $12 \%$. In the EU28 this meant also a decline in transport volume, in China the peak year was in 2011, since then it is constantly dropping. These figures show that rail transport is less and less efficient. The figures hide the difference in separate goods group. However, in China the main problem for railways is the closing of coal mining.

The average distance of freight rail traffic in China was $722 \mathrm{~km}$ in 2014. This is almost the same as in $1991(718 \mathrm{~km})$. Despite the massive railway infrastructure projects, the freight-only corridors, the speed raising on lines, the high distance traffic is still more viable on other transport modes - namely waterways, where the average distance was $1866 \mathrm{~km}$ in 2014, up from 1554 in 1991.

For the EU-China traffic, the container traffic is especially interesting, and it has been growing in the EU in the last decade. The share of unitised traffic grew from 14 to 17\% from 2007 to 2014. It is the highest in Ireland with 53\%, but lower than average in the Central-Eastern-European countries, only 10-13\% which are much more interesting for the EU-China rail trade, as they are landlocked. The rise of container traffic represents the changing industry needs, moving away from bulk products such as iron ore, coal etc. to machinery and electric goods.

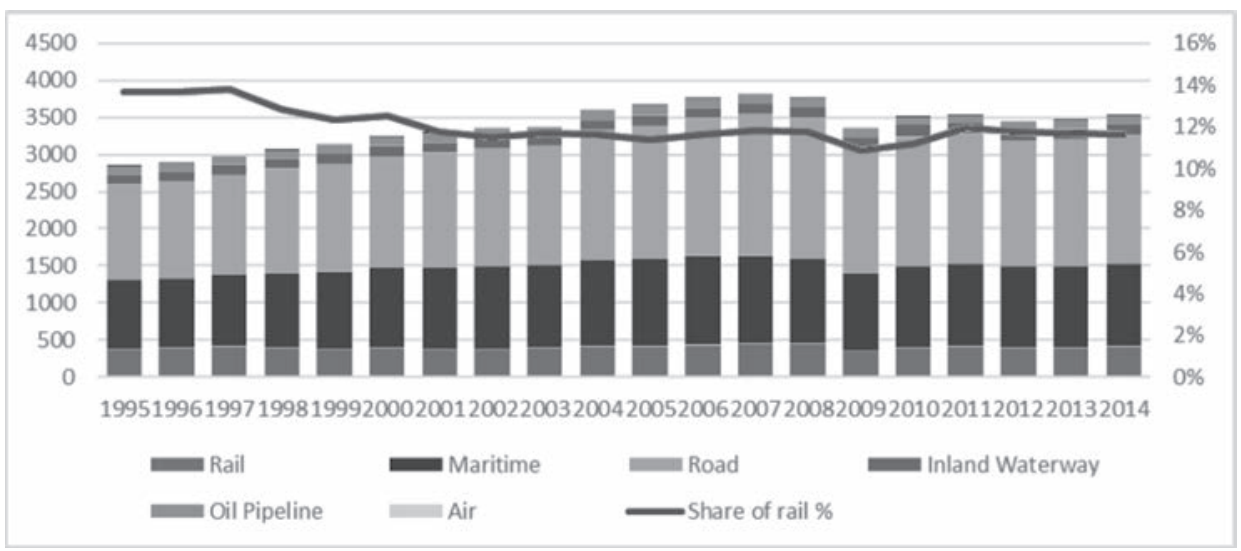

Figure 1. Freight Ton-Kilometres (1 billion ton-km) by mode of transport, European Union Source: (European Commission Transport Pocketbook) 


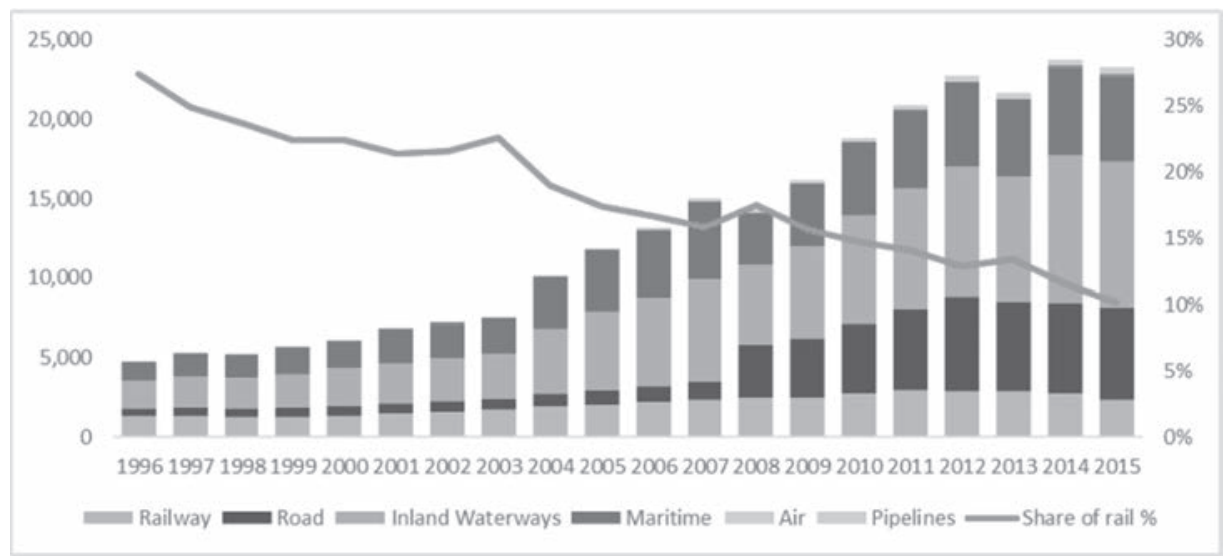

Figure 2. Freight Ton-Kilometres (1 billion ton- $\mathrm{km}$ ) by mode of transport, China Source: (National Bureau of Statistics of China)

\section{Lack of containerised railway services in China}

There is also a significant change in China: according to a World Bank (2015) report the relocation of industrial production westwards, inland in the period between 1998 and 2007 saw a breath-taking growth in the transport sector. In this 15 years the average GDP growth was $9.7 \%$, and the ton- $\mathrm{km}$ growth rate $10.4 \%$. In this period rail transport lost a significant share as it can be seen in Figure 1.

China would be an ideal country to transport long distance containerised traffic by rail - similarly to the US - but due to the lack of sufficient services this type of traffic is handled more on road. According to World Bank (2015) that in 2010 only $1.3 \%$ of traffic to and from Chinese ports was trafficked via rail. This shows also the limited capabilities of overland containerised traffic.

Monios and Wang (2013) analysed the network of dry ports in China: the first one was opened in 2002, and in 2013 there were only 20 significant in the whole country. It is important to emphasize the role of customer support: as road freight services are competitive in China, it can rapidly adapt to market needs. In China in 2012, rail container traffic represented only $2.38 \%$ of total railway freight traffic by weight, compared with 37\% in the United States and 20\% in the European Union as it can be read in ADB (2016) report. The National Bureau of Statistics of China published the data on railway container traffic for the first time in 2016, and it shows that only $3 \%$ of railway freight volume was container traffic.

The foundation of CR Intermodal is a good way ahead: with its five shareholders from state owned entities to private sector it created 18 modern rail ports in the country, but this number is very low compared to the size of the country. A significant growth is needed to facilitate China-Europe rail traffic.

According to industry benchmark (World Bank, 2011), intermodal trains can be profitable to road transport above a distance of $500-700 \mathrm{~km}$. However, there is no data available to compare it with maritime transport. Although Chinese railway market started to move slowly into the direction of container rail transport, still 
more than $90 \%$ of goods are bulk materials, and it will be a slow and long process to change the infrastructure (rail wagons, rail ports, IT) according to the market needs. In addition, until inside China the market push is greater for container rail traffic than the supply, it is hard to deliver goods in greater quantity to trans-Eurasian traffic.

\section{China's freight rail developments}

The Chinese rail freight system has developed in the recent 15 years. Until 2000 maximum wagon capacity was 60 tons and the axle load 20.3 tons (World Bank, 2008). Since 2004 all new freight wagons have had at least a maximum capacity of 70 tons, and an axle load of 23 tons, with maximum speed of $120 \mathrm{~km} / \mathrm{h}$. In contrast, in Europe where the common maximum speed is still $100 \mathrm{~km} / \mathrm{h}$, and the $22.5 / 25$ tons axle loads are only common in dedicated freight rail corridors. In Europe average maximum train length can only be $0.7-0.8 \mathrm{~km}$, while in China $2.7 \mathrm{~km}$, which makes the efficient Trans-Eurasian trains less effective, as the operators have to use for the whole way the European maximum length and tonnage (CER, 2016). On the route in the CIS countries even higher efficiency can be achieved, which makes short and relatively small transcontinental direct trains relatively less efficient. In the plans of the Russian Railways (RZD) the axle load will be risen to 38 tons and total capacity to 80 tons, freight trains can achieve 10 thousand tons and a maximum speed of $120 \mathrm{~km} / \mathrm{h}$ (Goncaharov, 2011).

\section{Data on the role of rail transport on the Eurasian route}

The European Commission collects data on trade, and within the trade statistics the mode of transport is also amiable. When we look at the data of countries that lie on the iron Silk Road, we can see that the share of railway is very low, with only $1-2 \%$ in tons. The only exception are the landlocked countries of the Kyrgyz Republic, Mongolia and Uzbekistan, but they have negligible traffic with the EU. The highest share of railway traffic has been seen with Ukraine, but it is the closest country to Europe with less developed roads, but good rail system. Even with Russia, in terms of weight of goods the share of railway is only $7 \%$. This shows that even if there is a well-established rail logistics market between a country and the EU, rail not necessary plays a significant role. 


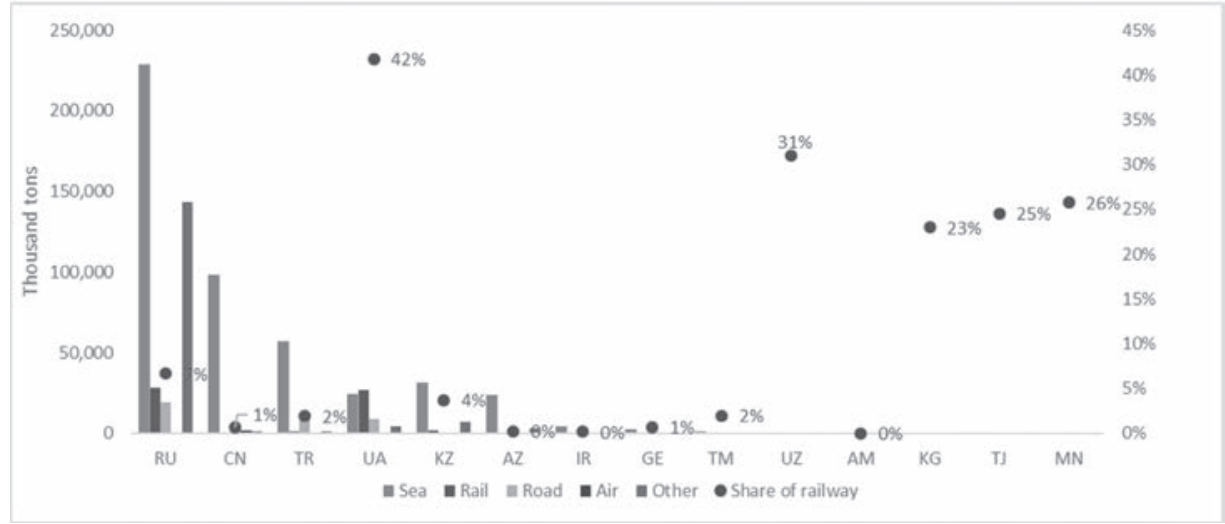

Figure 3. Volume of EU Trade (export and import) by mode of transport with Silk Road countries (tons)

Source: (own calculations based on: European Commission Market Access Database)

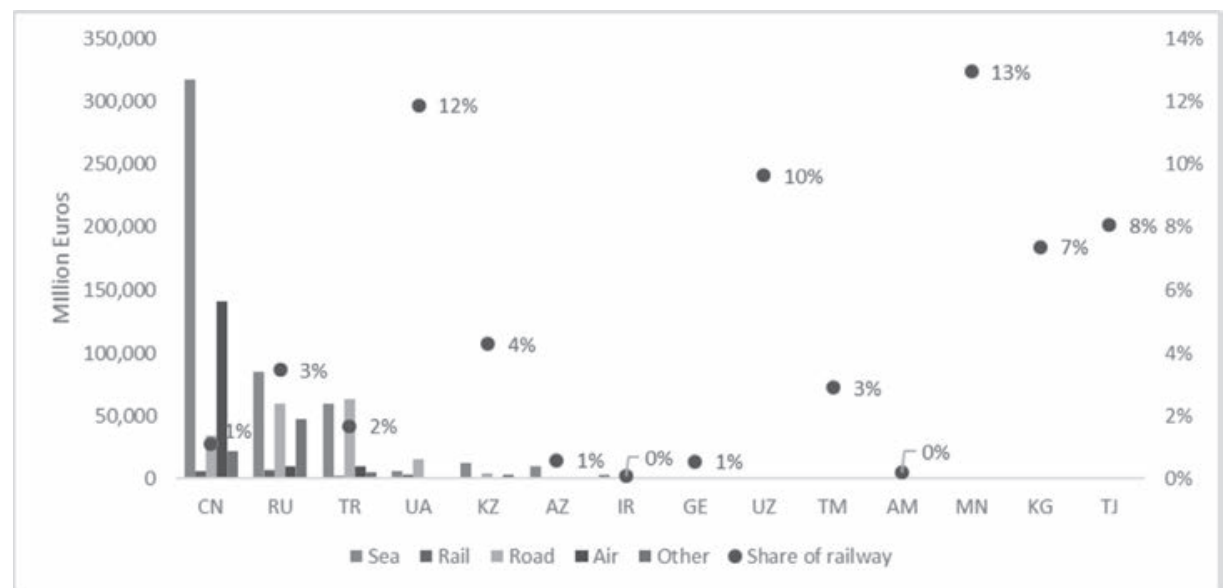

Figure 4. Value of EU Trade (export and import) by mode of transport with Silk Road countries (euros)

Source: (own calculations based on: European Commission Market Access Database)

It can be seen, that the share of goods transported by rail is higher value than by volume, which is what we would normally assume, as cheaper goods are to be transported by waterways. The next Figure shows that value per tons is similar in the observed countries. Goods transported between China and the EU have almost 5 times higher value, than to other countries to the Silk Road. This shows that it is only efficient to travel the long journey, if the value is higher.

For the trade between China and the EU28 there is data for value (since 2002) and volume (since 2000). The constant growth of trade between the two regions was not similar in all traffic segments. Rail traffic had a share in value in 2015 of $1.5 \%$, and by volume of $0.7 \%$. Except for goods imported from China there is no 
considerable growth, and the relative position of freight rail within the modal split is around the same as it used to be at the beginning of the new millennium. What is important to mention that air traffic is still much bigger - more than twice as higher in volume, and 25 times higher in value.

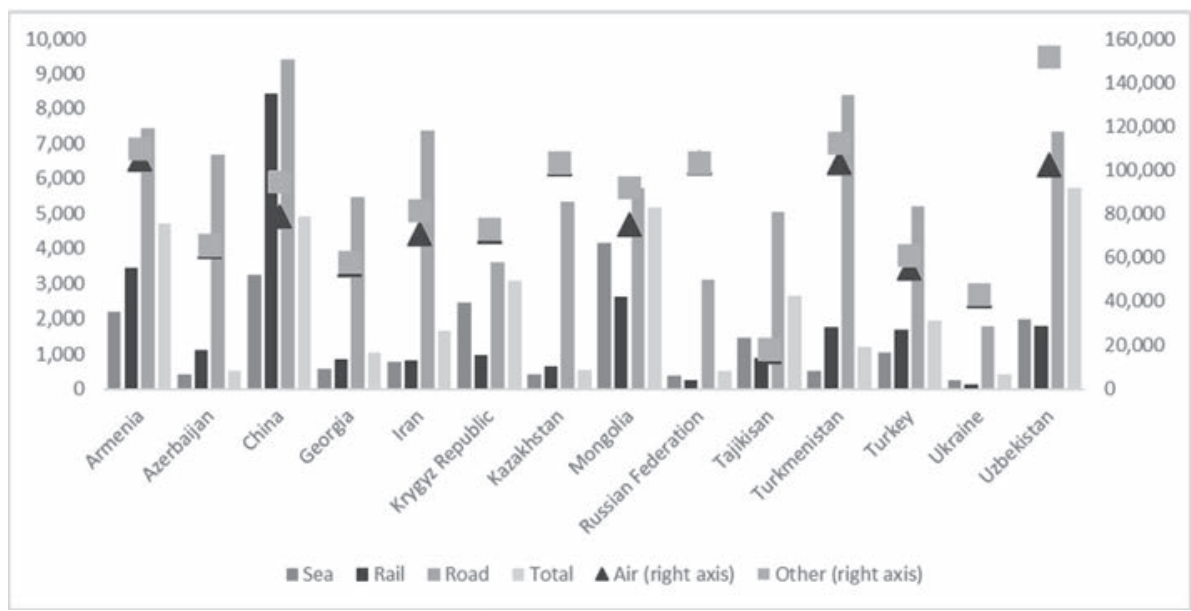

Figure 5. Value of goods of EU trade (export and import) with Silk Road countries (share on right axis) [euros/tons]

Source: (own calculations based on: European Commission Market Access Database)

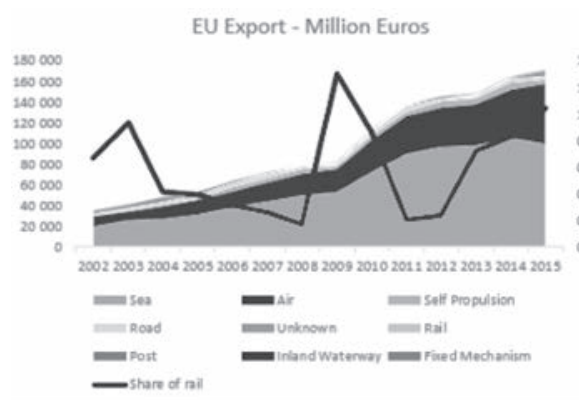

EU Import - Million Euros

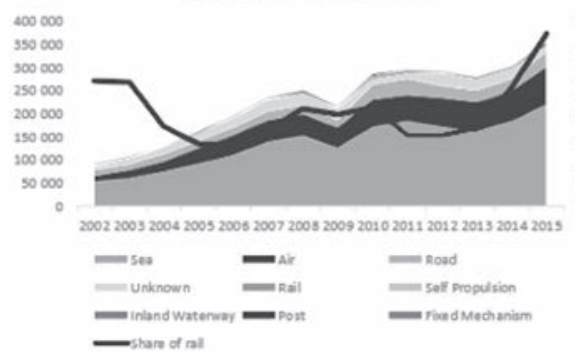

EU Export - Thousand Tons

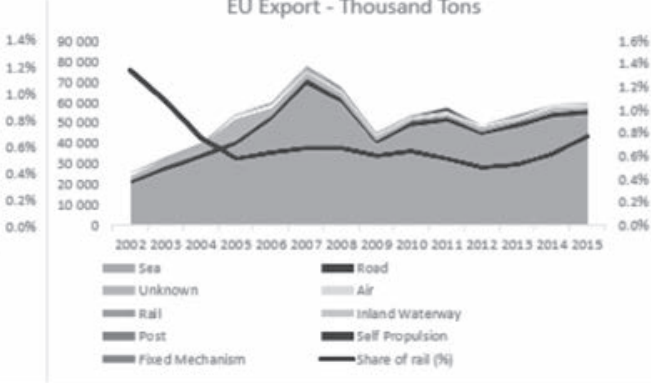

EU Import - Thousand Tons

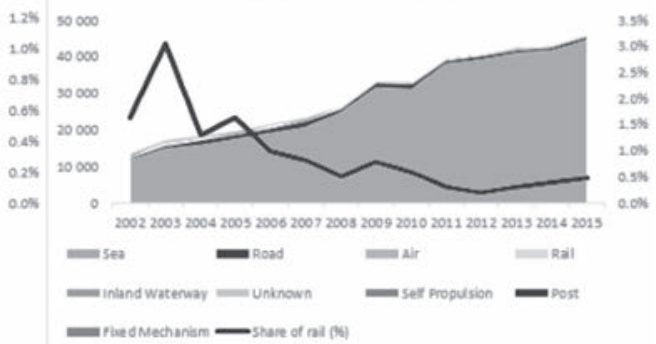

Figure 6. Development of EU-China trade by mode of transport by value and volume Source: (own calculations based on: European Commission Market Access Database) 


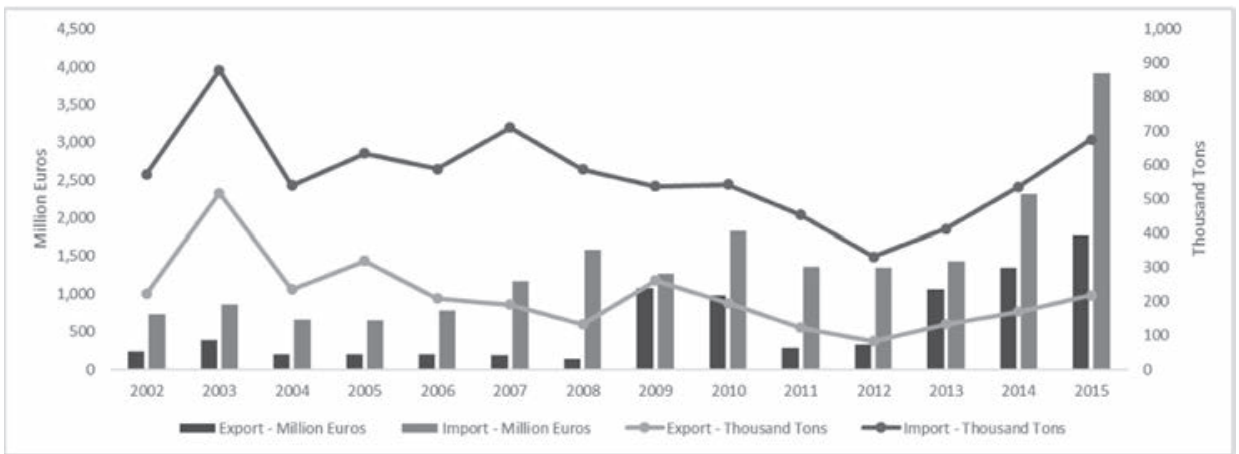

Figure 7. Imports and export from / to China from the European Union by volume and value Source: (own calculations based on: European Commission Market Access Database)

The rail traffic between the Central-Asian countries is intensive, but the EU-China traffic is only a negligible fraction of it. When we compare the rail traffic of goods on the Kazakh, Russian and Mongolian borders to China, it can be seen that the EU-China rail traffic is only $1 \%$ of it.

Table 3. Rail transport of goods on borders in relationship with EU-China trade, 1000 tons

\begin{tabular}{|l|l|r|r|c|}
\hline \multicolumn{1}{|c|}{ Country 1 } & \multicolumn{1}{c|}{ Country 2 } & From 1 to 2 & From 2 to 1 & Total \\
\hline China & Russia & 21,370 & 22,978 & 44,348 \\
\hline China & Kazakhstan & 7,110 & 3,278 & 10,388 \\
\hline China & Mongolia & 8,290 & 5,370 & 13,660 \\
\hline \multicolumn{2}{|c|}{ Total } & 36,770 & 31,627 & 68,397 \\
\hline China & EU27 & 457 & 218 & 675 \\
\hline \multicolumn{2}{|c|}{ Share of EU-China rail traffic } & $1.2 \%$ & $0.7 \%$ & $1.0 \%$ \\
\hline
\end{tabular}

Source: (own calculations based on: OSJD (2016) and European Commission Market Access Database)

The transport with China is extremely concentrated on a few Central-European countries: $46 \%$ of all value of rail traffic was transported from or to Germany, the second most important country was the Czech Republic with $35.3 \%$. Above $1 \%$ was Slovakia (4.8\%), Poland (4.6\%), Austria (3.2\%), Hungary (1.4\%) and the Netherlands (1.4\%). Germany and the Czech Republic saw also the highest rates of average growth between 2000 and 2015 .

If we take a look at the type of goods transported by rail between EU and China it gives an explanation why Germany and the Czech Republic are two of the most important countries: the bulk of the goods transported are machinery products.

From the 99 total product categories, the top 15 accounted for $95 \%$ of the traffic in value. In the export main products are vehicles from Germany, it includes main parts for automotive industry. Together with machinery it accounts two thirds for all exports. From the imports machinery products are in the first position, followed by electrical machinery. The machinery products are imported in $90 \%$ 
to Germany and the Czech Republic, whereas electrical machinery is delivered mainly to the Czech Republic.

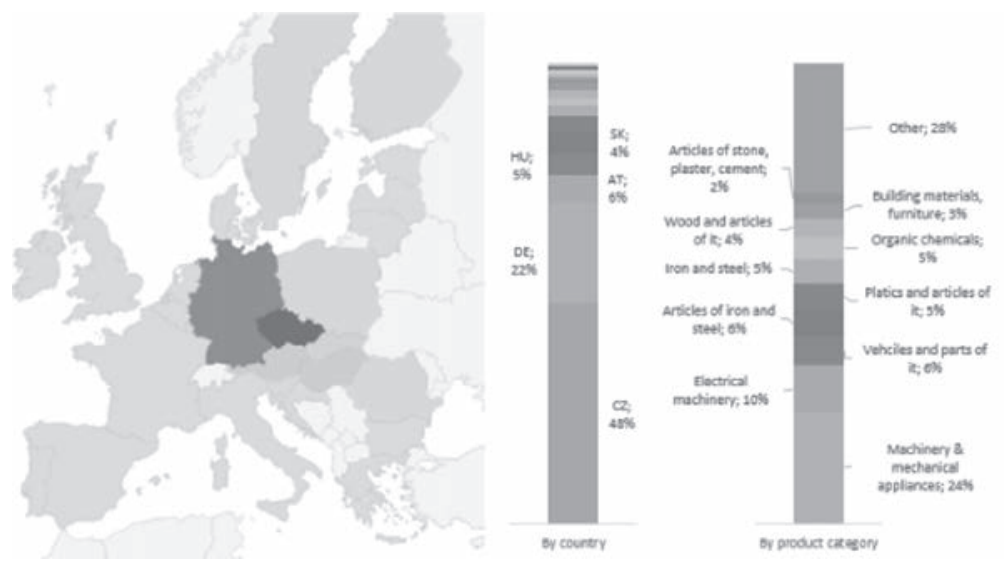

Figure 9. EU-China trade by rail in 2015 in volume (tons) - distribution by country and by product category (tons on right axis)

Source: (own calculations based on: European Commission Market Access Database)

\section{Eurasian container rail market}

\section{Market characteristics}

This renaissance of rail transport began on October 6. 2008, when the first direct container train arrived in Hamburg, Germany 17 days after departing from Xiangtan in Hunan province. Although this service was ground-breaking, it was also too inconsistent and too slow to gain any real market appeal. Since then, still DB Cargo has been playing the most important role in this traffic.

There are two-three dozens of corporations which are active on the Europe-China rail freight market, and in recent years the container trains between the two economies has been in the spotlight of international media. Although container train traffic is only a part of the whole rail freight market, there has been news of newer and newer links between Chinese and European cities. Most of this traffic is organised by Trans-Eurasia Logistics GmbH (TEL), a subsidiary of the German DB Cargo AG and the Russian state railway, RZD. Almost all trans-Eurasian trains run through Kazakhstan, Russia, Belarus, and reach Europe in Poland, from where DB Cargo has shuttle train connections to the whole Central-European region.

TEL is an interesting corporation, as its sole operation is to organise Eurasian block trains, and so its financial data can show the development of the traffic. Other major players on this market (DHL, DB Cargo, Gefco, etc.) do not publish data on their Eurasian block train operations.

In 2015 the revenue of TEL was 35 million euros, which is a massive growth after 19 million in 2014 and 21 million in 2013. However, if we compare this value to the total 2015 revenue of 4.2 billion income of DB Cargo AG this value is only $0.8 \%$. 
And DB is just one partner of the several companies involved in the transports. The income of TEL has to be shared on the 10-12 thousand $\mathrm{km}$ routes to Asia, which shows again that this a marginal business. The report of SCI assumes that the European rail market volume is 17.5 billion euros (SCI, 2016), which means that the container traffic between Europe and Asia is around $0.1 \%$ of the complete European rail market. The rail traffic is around 12\% of European transport market, we can see that the Eurasian landbridge is a negligible part of European transport.

CIT (2015) had the information that TEL transported 28,000 TEU containers from China to Europe and vice versa in 2014, and in 2012 it was only 4 thousand containers. If we take the 21 million euros income in 2014 that would mean that TEL had an income of 678 euros on one container, which can be realistic, as the company is the organiser of the transports, and the involved railway undertakings have to receive most of the income for their services. As there are many involved parties in one transport (logistics centre, logistics service provider, vehicle owner, vehicle manager, traction provider, network operator, railway undertaking, etc.) it is very challenging to divide the income and the cost of the transport. If we assume that TEL's income was similar per container in 2015, they were involved in the transport of 51622 TEU.

The maximum capacity of a 20 foot TEU is 21 tons. Even with full load assumption, transports in which TEL was involved in 2015 were 1 million tons of goods. From Eurostat data the EU - China transport of goods was 456 million tons. That means that container traffic of TEL accounted for $0.2 \%$ of the total EU - China railway traffic. However, the income of TEL includes a substantial amount of income of transport to and from Russia and other CIS countries, the China traffic cannot be separated from their books.

The published data of OSJD can be more reliable on the container traffic: UNECE (2017) received the information that in 2015 there were 815 scheduled container trains between Europe and China (550 westbound and 265 eastbound). On 26th of May China Railway announced that they achieved the 1000th train in 2017, but were not disclosing any statistics upon request. The National Development and Reform Commission of China is foreseeing 5000 Europe-China trains for 2020. In interviews with railway professionals the estimations of the number of current trains were around 1,500-2,000 for this year.

Even If we assume that 2000 trains will be travelling the Trans-Eurasian route this year with the maximum load of 100 TEU per train that equals 200000 TEU per year. As a container ship transports 10-20 thousand TEU, the rail capacity is very limited.

The forecast of 5000 trains annually with maximal load could mean 5 million tons of traffic, which is much higher than the 0.6 million tons of all railway traffic in 2015 , but still $5 \%$ of all current transport, but as transport volume will be growing, the share will also become lower.

\section{Costs of transport}

In theory, sea transport is for cheap goods, air for expensive goods, and it can be seen in table 4 that the value of 1 ton goods transported by air on average are 
30 times higher, while rail goods are 4 times more expensive. Thus, the traffic development of different transport modes will be characterised by the goods types transported. Very expensive small items like electronics are suitable for air transport, cheap bulk products like clothes for maritime, and for rail the heavy but expensive machinery products and automotive products can be suitable.

The higher costs of rail can be viable in cases if production is delayed, and fines should be paid by suppliers for belt stop. In these cases, the more expensive rail route can be financially more viable. Furthermore, if new products have to arrive to markets on time, the cost of time is again higher. What was also mentioned as a driver to use rail was the bankruptcy of Hanjin. Corporations were looking for alternatives as their cargo got stuck on ships for several months. This helped them to look for rail as an alternatives - especially in vis-major cases.

Table 4. Value of goods transported by different transport modes

\begin{tabular}{|l|c|r|r|r|}
\hline $\begin{array}{c}\text { Mode } \\
\text { of transport }\end{array}$ & Thousand tons & Million Euros & Euros / tons & $\begin{array}{c}\text { Value of 20 tons } \\
\text { in 1 TEU }\end{array}$ \\
\hline Sea & 44,402 & 318,121 & 7,165 & 143,293 \\
\hline Rail & 218 & 5,681 & 26,065 & 521,300 \\
\hline Road & 717 & 34,309 & 47,838 & 956,763 \\
\hline Air & 699 & 140,824 & 201,418 & $4,028,364$ \\
\hline
\end{tabular}

Source: (own calculations)

It is not easy to gain access to transport costs between China and Europe. Rail prices will likely shrink due to higher volume, but still maritime transport will be by far the cheapest, 1 000-1 500 euros/container between Europe and China, by rail it is around 5000 euros, by air above 20.000 euros.
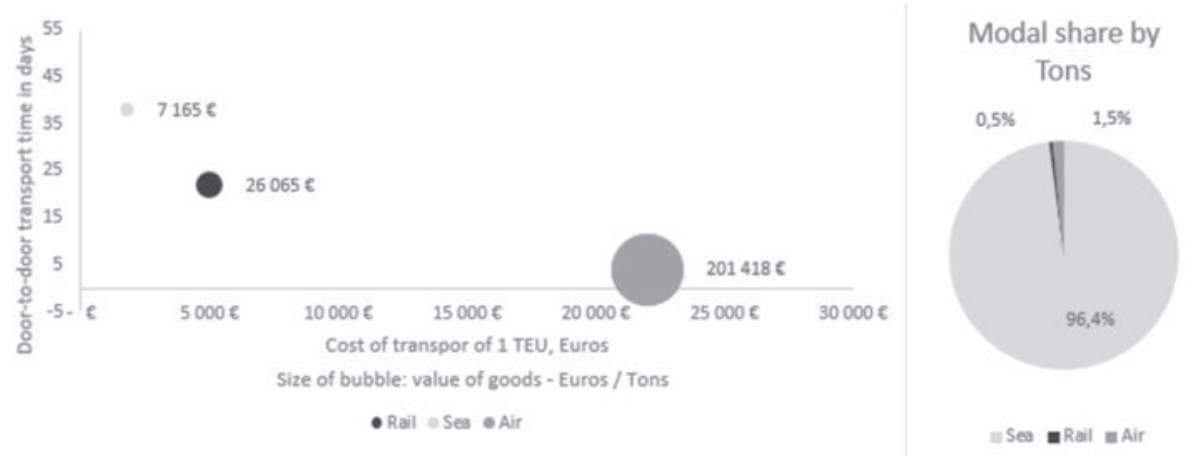

Figure 10. Modal split, cost and travel time of goods transported between EU and China in 2015

Source: (own calculations) 
In the near future the price of maritime transport is likely to decrease further, there are overcapacities as global trade is growing slower than expected. This is making it harder for rail transport to be more attractive.

The biggest concern about the viability of Eurasian cargo trains is the economical rationality. Gerden (2016) assumes that the subsidies of the Chinese government can reach 50\% of transport costs. Shepard (2016) reported subsidies in the value of billions of dollars. As there is no possibility to analyse detailed information we can conclude that subsidies play a great role of the expansion on the Eurasian container train growth.

\section{Conclusions}

The Silk Road is a two-thousand-year-old trade route, which saw its decline due to the development of maritime transport. In the recent decade the idea of the revival of the route as an Iron Silk Road has become popular, and container traffic has started to grow between China and Europe. Although numerous new direct train routes have been opened with faster delivery times, the statistical data suggests that the relevance of railway transport is still negligible for the trade between China and the European Union, and there is no sign that it will change in the future significantly.

In geopolitical terms the existence and the possibility of railway connections and the planned extension and upgrade of the physical infrastructure is important. However, for the highly competitive transport business that is not enough. For the supply chain networks the connected logistics services and the efficiency is maybe even more important. High subsidies, red tape and low quality services along the Silk Route make rail freight traffic less attractive in the longer term.

On the other hand China plans to produce more advanced machinery products, and especially these are the ones transported the most on the Trans-Eurasian route. But even in this case, and future developments in both network and developments of services the rail transport will be most probably a marginal option compared to the much cheaper maritime routes.

\section{References}

Abramović, B., Vladislav, Z., and Vedran, B. (2016), Organisation of railway freight transport: case study CIM/SMGS between Slovakia and Ukraine European Transport Research Review, $8(27)$.

ADB (Asian Development Bank) (2016), Completion Report, People's Republic of China: Railway Container Transport Development Manila: ADB. Available from https://www.adb.org/sites/ default/files/project-document/191071/47065-001-tcr.pdf.

Alff, H. (2016), Flowing goods, hardening borders? China's commercial expansion into Kyrgyzstan re-examined, Eurasian Geography and Economics, 57(3).

Aoyama, R. (2016), One Belt, One Road: China's New Global Strategy, Journal of Contemporary East Asia Studies, 5(2).

Bajor, T., Erdösi, F. (2013), Alternative Routes Between the Far East and Europe (With Special Regard to the Foreign Trade of Hungary Discussion Paper No. 90. Pécs: Institute For Regional 
Studies Centre For Economic And Regional Studies Hungarian Academy Of Sciences. Available from http://discussionpapers.rkk.hu/index.php/DP/article/viewFile/2553/4662 [Accessed 13 March 2017].

Casarini, N. (2016), When All Roads Lead to Beijing. Assessing China's New Silk Road and its Implications for Europe, The International Spectator, 51(4).

CER (Community of European Railway and Infrastructure Companies) (2016), Longer trains Facts $\mathcal{E}$ Experiences in Europe Results of the CER working group on longer and heavier trains, Brussels. Available from http://www.cer.be/sites/default/files/publication/160525 Longer\%20Trains_Facts\%20and\%20Experiences\%20in\%20Europe_final_0.pdf [Accessed 12 March 2017].

Chen, C-L (2012), Reshaping Chinese space-economy through high-speed trains: opportunities and challenges, Journal of Transport Geography, 22.

CIT (International Rail Transport Committee) (2016), CIM/SMGS Consignment Note Manual (GLV CIM/SMGS). Available from www.cit-rail.org\%2Ffiles\%2FDocumentation_EN\%2FFreight $\%$ 2FGLV-CIMSMGS\%2FAmendment_22_GLV_CIM-SMGS_EN_2016-07-01.pdf.

Diener, A.C. (2015), Parsing mobilities in Central Eurasia: border management and New Silk Roads Eurasian Geography and Economics, 56.

Gerden, E. (2016), China may heavily subsidize container rail shipments to Russia, Journal of Commerce, January 29. Available from http://www.joc.com/rail-intermodal/ international-rail/asia/china-may-heavily-subsidize-container-rail-shipments -russia 20160129.html.

Mautris, E. (2015), China's Silk Road initiatives could shake up European port cities' status quo China Economic Review, September 8. Available from http://www.chinaeconomicreview.com/chinas-silk-road-initiatives-could-shake-european-port-cities-status-quo.

Erdösi, F. (2015), Trans-Eurasian transport links in great and medium-size spaces of power, Tér és Társadalom (Space and Society), 29(2).

Farkas, A.Z., Pap, N., Reményi, P. (2016), Hungary's place on Eurasian rail land bridges and the eastern opening, Hungarian Geographical Bulletin, 65(1).

Garver, J.W. (2006), Development of China's Overland Transportation Links with Central, South-west and South Asia, The China Quarterly, 185(3).

Hilletofth, P, Lorentz, H., Savolainen V-V., Hilmola, O-P., and Ivanova, O. (2007), Using Eurasian landbridge in logistics operations: building knowledge through case studies, World Review of Intermodal Transportation Research, 1(2).

Hofman, I. (2016), Politics or profits along the Silk Road: what drives Chinese farms in Tajikistan and helps them thrive?, Eurasian Geography and Economics, 57(3).

Kennedy, S. (2015), Made in China 2025, Center for Strategic and International Studies, June 1 https://www.csis.org/analysis/made-china-2025.

Leimgruber, T. (2009), Common CIM-SMGS consignment note for international rail transport Presentation, Teheran, https:/www.unece.org/fileadmin/DAM/trans/doc/2009/wp5/GE2wkshp1-CIT.pdf .

Loughlin, P.H., Pannell, W.C. (2001), Growing Economic Links and Regional Development in the Central Asian Republics and Xinjiang, China, Post-Soviet Geography and Economics, $42(7)$.

Monios, J., Yuhong, W. (2013), Spatial and institutional characteristics of inland port development in China, GeoJournal, 78.

OECD (2010) Globalisation, Transport and the Environment. Available from http://www.keepeek. com/Digital-Asset-Management/oecd/environment/globalisation-transport-and-the-environment_9789264072916-en\#page130.

OSJD (2016), OSJD Bulletin of statistical data on railway transport for 2015. Available from http:// en.osjd.org/dbmm/download? $v p=68 \& l o a d=y \& c o l \_i d=121 \& i d=350$. 
Otsuka, S. (2001), Central Asia's Rail Network and the Eurasian Land Bridge, Japan Railway $\mathcal{E}$ Transport Review, 28(9).

Peyrouse, S., Raballand, G. (2015), Central Asia: the New Silk Road Initiative's questionable economic rationality, Eurasian Geography and Economics, 56(4).

Rodemann, H. Templar, S. (2014), The enablers and inhibitors of intermodal rail freight between Asia and Europe, Journal of Rail Transport Planning \& Management, (4)3.

SCI (2016) European Rail Freight Transport Market Developments - Volumes - Players. SCI/ VERKEHR. Available from https://www.sci.de/uploads/tx_edocuments/Flyer_MC_Rail_ Freight_Transport.pdf.

Shepard, W. (2016), How Those China-Europe 'Silk Road' Trains First Began, Forbes, June 29. Available from https://www.forbes.com/sites/wadeshepard/2016/06/29/the-story-of-how-those-china-europe-silk-road-trains-first-began/print/.

Shu, X. (1997), The New Asia-Europe Land Bridge - Current Situation and Future Prospects, Japan Railway \& Transport Review, 14(12).

Szakonyi, M. (2013), Intermodal on Slow Track in China, Journal of Commerce, December 18. Available from http://www.joc.com/rail-intermodal/international-rail/asia/intermodal-slo w-track-china_20131218.html.

Tavasszy, L., Minderhoud, M. Perrin, J-P., Notteboom, T. (2011), A strategic network choice model for global container flows: specification, estimation and application, Journal of Transport Geography 6(5).

The Diplomat (2017), The Turkmenistan-Afghanistan-Tajikistan Railway. Available from http:// thediplomat.com/2016/12/the-turkmenistan-afghanistan-tajikistan-railway/ [Accessed 05.12.2017].

Tracy, E. F., Simonov, E., Babenko, M. (2017), China's new Eurasian ambitions: the environmental risks of the Silk Road Economic Belt, Eurasian Geography and Economics, 58(1).

UNECE (United Nations Economic Commission for Europe) (2017), Euro-Asian Transport links. Available from http://www.unece.org/fileadmin/DAM/trans/doc/2017/wp5-eatl/ Report_draft-07.04.2017_for_expert_comments.pdf.

WEF (World Economic Forum) (2017), How Technology Can Unlock the Growth Potential along the New Silk Road, White Paper, http://www3.weforum.org/docs/WEF_New_Silk_Road_ Pager_2017.pdf .

World Bank (2009), Tracks from the past, transport for the future China's Railway Industry 19902008 and its future plans and possibilities. https:/openknowledge.worldbank.org/bitstream/ handle/10986/3197/564150ESW0whit1al0published0version.pdf? sequence $=1$.

World Bank (2011), Railway Reform: Toolkit for Improving Rail Sector Performance. Available from https://ppiaf.org/sites/ppiaf.org/files/documents/toolkits/railways_toolkit/PDFs/ WB_toolkit.pdf

World Bank (2015) Customer-driven Rail Intermodal Logistics Unlocking a New Source of Value for China, http://documents.worldbank.org/curated/en/326271468018548105/pdf/950250WP00PUBL0China0Final0ENGLISH.pdf .

Wübbeke, J., Meissner M., Zenglein, M. J., Ives, J., Conrad, B. (2016) Made In China 2025 The making of a high-tech superpower and consequences for industrial countries Papaers on China Nno. 2., Merics. Available from https://www.merics.org/fileadmin/user_upload/ downloads/MPOC/MPOC_Made_in_China_2025/MPOC_No.2_MadeinChina_2025.pdf.

$\mathrm{Xu}, \mathrm{H}$. (2016), Domestic railroad infrastructure and exports: Evidence from the silk route, China Economic Review, 41(12).

\section{Corresponding author}

Peter Bucsky can be contacted at: peter.bucsky@gmail.com 